

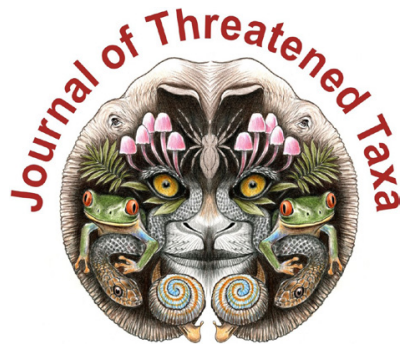

ISSN 0974-7907 (Online); ISSN $0974-7893$ (Print)

Publisher

Host

Wildlife Information Liaison Development Society

www.wild.zooreach.org

Zoo Outreach Organization www.zooreach.org

No. 12, Thiruvannamalai Nagar, Saravanampatti - Kalapatti Road, Saravanampatti, Coimbatore, Tamil Nadu 641035, India

Ph: +91 9385339863 | www.threatenedtaxa.org

Email: sanjay@threatenedtaxa.org

EDITORS

\section{Founder \& Chief Editor}

Dr. Sanjay Molur

Wildlife Information Liaison Development (WILD) Society \& Zoo Outreach Organization (ZOO),

12 Thiruvannamalai Nagar, Saravanampatti, Coimbatore, Tamil Nadu 641035, India

\section{Deputy Chief Editor}

Dr. Neelesh Dahanukar

Noida, Uttar Pradesh, India

\section{Managing Editor}

Mr. B. Ravichandran, WILD/ZOO, Coimbatore, India

\section{Associate Editors}

Dr. Mandar Paingankar, Government Science College Gadchiroli, Maharashtra 442605, India

Dr. Ulrike Streicher, Wildlife Veterinarian, Eugene, Oregon, USA

Ms. Priyanka Iyer, ZOO/WILD, Coimbatore, Tamil Nadu 641035, India

Dr. B.A. Daniel, ZOO/WILD, Coimbatore, Tamil Nadu 641035, India

\section{Editorial Board}

Dr. Russel Mittermeier

Executive Vice Chair, Conservation International, Arlington, Virginia 22202, USA

\section{Prof. Mewa Singh Ph.D., FASc, FNA, FNASc, FNAPsy}

Ramanna Fellow and Life-Long Distinguished Professor, Biopsychology Laboratory, and Institute of Excellence, University of Mysore, Mysuru, Karnataka 570006, India; Honorary Professor, Jawaharlal Nehru Centre for Advanced Scientific Research, Bangalore; and Adjunct Professor, National Institute of Advanced Studies, Bangalore

\section{Stephen D. Nash}

Scientific Illustrator, Conservation International, Dept. of Anatomical Sciences, Health Sciences Center, T-8, Room 045, Stony Brook University, Stony Brook, NY 11794-8081, USA

\section{Dr. Fred Pluthero}

Toronto, Canada

\section{Dr. Priya Davidar}

Sigur Nature Trust, Chadapatti, Mavinhalla PO, Nilgiris, Tamil Nadu 643223, India

\section{Dr. Martin Fisher}

Senior Associate Professor, Battcock Centre for Experimental Astrophysics, Cavendish

Laboratory, JJ Thomson Avenue, Cambridge CB3 OHE, UK

\section{Dr. John Fellowes}

Honorary Assistant Professor, The Kadoorie Institute, 8/F, T.T. Tsui Building, The University of Hong Kong, Pokfulam Road, Hong Kong

\section{Prof. Dr. Mirco Solé}

Universidade Estadual de Santa Cruz, Departamento de Ciências Biológicas, Vice-coordenado do Programa de Pós-Graduação em Zoologia, Rodovia Ilhéus/Itabuna, Km 16 (45662-000)

Salobrinho, Ilhéus - Bahia - Brasil

\section{Dr. Rajeev Raghavan}

Professor of Taxonomy, Kerala University of Fisheries \& Ocean Studies, Kochi, Kerala, India

\section{English Editors}

Mrs. Mira Bhojwani, Pune, India

Dr. Fred Pluthero, Toronto, Canad

Mr. P. Ilangovan, Chennai, India

Web Development

Mrs. Latha G. Ravikumar, ZOO/WILD, Coimbatore, India

\section{Typesetting}

Mr. Arul Jagadish, ZOO, Coimbatore, India

Mrs. Radhika, ZOO, Coimbatore, India

Mrs. Geetha, ZOO, Coimbatore India
Fundraising/Communications

Mrs. Payal B. Molur, Coimbatore, India

Subject Editors 2018-2020

Fungi

Dr. B. Shivaraju, Bengaluru, Karnataka, India

Dr. R.K. Verma, Tropical Forest Research Institute, Jabalpur, India

Dr. Vatsavaya S. Raju, Kakatiay University, Warangal, Andhra Pradesh, India

Dr. M. Krishnappa, Jnana Sahyadri, Kuvempu University, Shimoga, Karnataka, India

Dr. K.R. Sridhar, Mangalore University, Mangalagangotri, Mangalore, Karnataka, India

Dr. Gunjan Biswas, Vidyasagar University, Midnapore, West Bengal, India

\section{Plants}

Dr. G.P. Sinha, Botanical Survey of India, Allahabad, India

Dr. N.P. Balakrishnan, Ret. Joint Director, BSI, Coimbatore, India

Dr. Shonil Bhagwat, Open University and University of Oxford, UK

Prof. D.J. Bhat, Retd. Professor, Goa University, Goa, India

Dr. Ferdinando Boero, Università del Salento, Lecce, Italy

Dr. Dale R. Calder, Royal Ontaro Museum, Toronto, Ontario, Canada

Dr. Cleofas Cervancia, Univ. of Philippines Los Baños College Laguna, Philippines

Dr. F.B. Vincent Florens, University of Mauritius, Mauritius

Dr. Merlin Franco, Curtin University, Malaysia

Dr. V. Irudayaraj, St. Xavier's College, Palayamkottai, Tamil Nadu, India

Dr. B.S. Kholia, Botanical Survey of India, Gangtok, Sikkim, India

Dr. Pankaj Kumar, Kadoorie Farm and Botanic Garden Corporation, Hong Kong S.A.R., China

Dr. V. Sampath Kumar, Botanical Survey of India, Howrah, West Bengal, India

Dr. A.J. Solomon Raju, Andhra University, Visakhapatnam, India

Dr. Vijayasankar Raman, University of Mississippi, USA

Dr. B. Ravi Prasad Rao, Sri Krishnadevaraya University, Anantpur, India

Dr. K. Ravikumar, FRLHT, Bengaluru, Karnataka, India

Dr. Aparna Watve, Pune, Maharashtra, India

Dr. Qiang Liu, Xishuangbanna Tropical Botanical Garden, Yunnan, China

Dr. Noor Azhar Mohamed Shazili, Universiti Malaysia Terengganu, Kuala Terengganu, Malaysia

Dr. M.K. Vasudeva Rao, Shiv Ranjani Housing Society, Pune, Maharashtra, India

Prof. A.J. Solomon Raju, Andhra University, Visakhapatnam, India

Dr. Mandar Datar, Agharkar Research Institute, Pune, Maharashtra, India

Dr. M.K. Janarthanam, Goa University, Goa, India

Dr. K. Karthigeyan, Botanical Survey of India, India

Dr. Errol Vela, University of Montpellier, Montpellier, France

Dr. P. Lakshminarasimhan, Botanical Survey of India, Howrah, India

Dr. Larry R. Noblick, Montgomery Botanical Center, Miami, USA

Dr. K. Haridasan, Pallavur, Palakkad District, Kerala, India

Dr. Analinda Manila-Fajard, University of the Philippines Los Banos, Laguna, Philippines

Dr. P.A. Sinu, Central University of Kerala, Kasaragod, Kerala, India

Dr. Afroz Alam, Banasthali Vidyapith (accredited A grade by NAAC), Rajasthan, India

Dr. K.P. Rajesh, Zamorin's Guruvayurappan College, GA College PO, Kozhikode, Kerala, India

Dr. David E. Boufford, Harvard University Herbaria, Cambridge, MA 02138-2020, USA

Dr. Ritesh Kumar Choudhary, Agharkar Research Institute, Pune, Maharashtra, India

Dr. Navendu Page, Wildlife Institute of India, Chandrabani, Dehradun, Uttarakhand, India

\section{Invertebrates}

Dr. R.K. Avasthi, Rohtak University, Haryana, India

Dr. D.B. Bastawade, Maharashtra, India

Dr. Partha Pratim Bhattacharjee, Tripura University, Suryamaninagar, India

Dr. Kailash Chandra, Zoological Survey of India, Jabalpur, Madhya Pradesh, India

Dr. Ansie Dippenaar-Schoeman, University of Pretoria, Queenswood, South Africa

Dr. Rory Dow, National Museum of natural History Naturalis, The Netherlands

Dr. Brian Fisher, California Academy of Sciences, USA

Dr. Richard Gallon, llandudno, North Wales, LL30 1UP

Dr. Hemant V. Ghate, Modern College, Pune, India

Dr. M. Monwar Hossain, Jahangirnagar University, Dhaka, Bangladesh

Mr. Jatishwor Singh Irungbam, Biology Centre CAS, Branišovská, Czech Republic.

Dr. Ian J. Kitching, Natural History Museum, Cromwell Road, UK

Dr. George Mathew, Kerala Forest Research Institute, Peechi, India

For Focus, Scope, Aims, and Policies, visit https://threatenedtaxa.org/index.php/JoTT/aims_scope
For Article Submission Guidelines, visit https://threatenedtaxa.org/index.php/JoTT/about/submissions
For Policies against Scientific Misconduct, visit https://threatenedtaxa.org/index.php/JoTT/policies_various

continued on the back inside cover 


\title{
Phenotypic plasticity in Barilius vagra (Hamilton, 1822) (Teleostei: Danionidae) from two geographically distinct river basins of Indian Himalaya
}

\author{
Sumit Kumar ${ }^{1}$ (D), Sharali Sharma ${ }^{2}$ (D) \& Deepak Singh ${ }^{3}$ (D) \\ ${ }^{1-3}$ Freshwater Biodiversity Laboratory, Department of Zoology, H.N.B. Garhwal University, Srinagar (Garhwal), Uttarakhand 246174, India. \\ ${ }^{1}$ sumitsharmaraina2109@gmail.com, ${ }^{2}$ sharmashanali@gmail.com, ${ }^{3}$ bhandaridrdeepak5@gmail.com (corresponding author)
}

\begin{abstract}
Truss-based morphometric analysis was used to examine phenotypic plasticity of Barilius vagra (Hamilton, 1822) inhabiting the tributaries of the Alaknanda (Ganga River basin) and Chenab (Indus River basin), two geographically distinct river basins in the Indian Himalaya. Fourteen landmarks were connected to generate a truss network of 90 parameters on the body of fish. Eighty morphometric traits out of ninety morphometric measurements explained statistically significant difference among six sampling locations of Barilius vagra from streams in the Alaknanda and Chenab basins. Discriminant function analysis revealed $82 \%$ of Barilius vagra specimens originally classified into their own groups. $95 \%$ of the variance was explained by 13 principal components. Morphometric characters (1-6, $1-13,2-5,2-6,2-14,3-6,4-6,4-14,6-12,7-8,7-9,10-11$, and 13-14) contributed greatly in differentiation of $B$. vagra populations from different river basins. The Alaknanda basin reflected some mixing within populations, which may be due to common environmental conditions and fish migration in these streams. This study will be helpful in framing site-specific conservation and management strategies, such as net mesh size selection, avoiding overexploitation, stock augmentation and food availability for different fish populations.
\end{abstract}

Keywords: Danionidae, DFA, differentiation, morphometry, truss network.

Citation: Kumar, S., S. Sharma \& D. Singh (2021). Phenotypic plasticity in Barilius vagra (Hamilton, 1822) (Teleostei: Danionidae) from two geographically distinct river basins of Indian Himalaya. Journal of Threatened Taxa 13(13): 19976-19984. https://doi.org/10.11609/jott.7414.13.13.19976-19984

Copyright: (c) Kumar et al. 2021. Creative Commons Attribution 4.0 International License. JoTT allows unrestricted use, reproduction, and distribution of this article in any medium by providing adequate credit to the author(s) and the source of publication.

Funding: No funding received by the authors. However, Sumit Kumar got UGC non-NET fellowship through HNB Garhwal University during his PhD work.

Competing interests: The authors declare no competing interests.

Author details: DR. SUMIT KUMAR - presently working as wildlife biologist (fish) in a research project at Wildlife Institute of India, Dehradun. DR. SHARALI SHARMAspecialization in fishery science and presently working as Assistant Professor in Zoology at the Chandigarh University, Chandigarh, Punjab. DR. DEEPAK SINGHworking as an Associate Professor at the HNB Garhwal University, Srinagar (Garhwal).

Author contributions: SK-collected and analysed the data for the present study. SS-helped during sampling of fishes and contributed in writing the manuscript. DS-supervised during the whole study, checked the manuscript and helped in data analysis and interpretation.

Acknowledgements: The library and laboratory facilities during the present investigation provided by the Department of Zoology, H.N.B. Garhwal University, Srinagar (Garhwal) are hereby thankfully acknowledged. 


\section{INTRODUCTION}

Phenotypic plasticity is the ability of an organism to change especially in response to varying environmental conditions (Sahoo et al. 2020). Long term geographic isolation and limited migration causes phenotypic plasticity among the population within a species (Cadrin 2005). The Alaknanda and Chenab rivers drained from the Indian Himalaya are geographically isolated and rich in fish fauna.

Fishes show higher degree of variation within and between populations than other vertebrates, and they are more susceptible to environmentally induced morphological variation (Wimberger 1992). It has been suggested that the morphological characters of fish are determined by environment, genetic and interaction between them (Poulet et al. 2004). During the early development stages the individual's phenotype is more amenable to environment influence (Pinheiro et al. 2005). The phenotypic variability may not necessarily reflect population differentiation at genetic level (Ihssen et al. 1981). A sufficient degree of isolation may result in notable phenotypic and genetic differentiation among fish populations within a species, as a basis for separation and management of distinct populations (Turanet al. 2004).

Among the various tools used for stock assessment and phenotypic plasticity, morphometry is one of the frequently used and cost-effective tools. Traditional multivariate morphometrics, accounting for variation in size and shape have successfully discriminated between many stocks (Turan 1999). As the traditional morphometric measurements have biased coverage and metric selection over the body structure of fishes under experimentation, this method might not be useful for discriminate species when there is morphological plasticity (Takács et al. 2016). However, with the time this traditional method has been enhanced by image processing technique which is more effective in description of shape and stock identification (Mir et al. 2013).

Advance tool kits such as truss network system and geometric morphometrics is the best alternative used to study phenotypic plasticity within and between species (Turan 1999). Truss morphometric approach is an effective method for capturing information about the shape of an organism (Cavalcanti et al. 1999). It has been used to identify stocks of many fish species from marine and fresh waters (Sajina et al. 2011; GarciaRoudriguez et al. 2010; Sen et al. 2011; Khan et al. 2012; Miyan et al. 2015, Dwivedi et al. 2019). Different stocks identified on the basis of environmentally induced morphometric variations play a significant role in the fisheries management (Begg et al. 1999). Insufficient knowledge on the population structure hinders the rate of production and reduces yields (Cadrin 2005). Good knowledge and right information of fish stocks will help us in the proper management and conservation of endangered species and stock enhancement of cultivable species.

Bariline fishes belonging to family Danionidae are characterized by a compressed body, blue-black bars or spots on the body and dorsal fin inserted behind the middle of the body (Rahman, 1989). Thirty-two bariline species are reported globally out of which 23 species so far reported from India (Singh et al. 2016). The species of genus Barilius including Barilius vagra (Hamilton, 1822) are commonly called hill trouts. These minnows inhabit both shallow lentic and lotic waters of Himalayan region (Sahoo et al. 2009). The hill stream fishes are important part of food as well as source of income to the fishermen of the Himalayan region (Kumar \& Singh 2019). There are a few studies available on the population structure of Barilius bendelisis (Mir et al. 2015; Saxsena et al. 2015; Kumar \& Singh 2019). However, there is paucity of published information on the population structure of Barilius vagra from Indian waters. Therefore, the present study was carried out with the objective to examine the phenotypic plasticity among the different populations of $B$. vagra from two distinct river basins of Indian Himalaya.

\section{MATERIALS AND METHODS}

\section{Sampling and Measurements}

Total 257 Barilius vagra specimens were sampled from Alaknanda River basin (132 specimens) and Chenab River basin (125 specimens) of Indian Himalaya using different fishing gears (cast nets and gill nets) from March 2015 to April 2017. The GPS coordinates; altitude and number of samples from each site of two river basins are presented in Table 1 . The specimens of Barilius vagra were collected before the breeding season and after the spawning period (April to June) to avoid a bias towards size difference. The fish specimens were identified by using identification keys of Mirza (1991), Talwar \& Jhingran (1991), and Kullander et al. (1999). After image capture, each fish was dissected for sex determination by macroscopic examination of the gonads. The gender was used as the class variable in ANOVA to test for significance difference in morphometric characters, if any, between male and female of $B$. vagra. 
The truss network system described by Strauss \& Bookstein (1982) was used to extract the 90 morphometric measurements of fish. Fish specimens were placed on water resistant graph paper as background and a digital camera of (Nikon D3400) was used to take the photographs (Figure 1) from same height and angle. Some specimens were submitted to the animal museum of the Department of Zoology of H.N.B. Garhwal University, Uttarakhand and others were fixed in $10 \%$ formalin solution for preservation.

The truss protocol used for the hill trout in the present study was based on 14 landmarks and the truss network constructed by interconnecting them to form a total of 90 truss measurements (Figure 1). The extraction of truss distances from the digital images of specimens was conducted using linear combination of three softwares, tpsUtil, tpsDig2 v2.1 (Rohlf 2006) and Paleontological Statistics (PAST) (Hammer et al. 2001).

\section{Data analysis}

Size dependent variations in truss measurements were removed, using the equation given by Elliott et al. (1995) as “ $M_{\text {adj }}=M\left(L_{s} / L_{0}\right)^{b "}$ Here $M_{\text {adj, }}$ is size adjusted measurement, $M$ is original measurement of length, $L_{0}$ is standard length of fish, $L_{s}$ the overall mean standard length, and $b$ slope of the regression of $\log M$ on $\log L_{0}$ which is estimated for each character from the observed.

Univariate analysis of variance (ANOVA) was applied to 90 morphometric characters to evaluate the significance of difference among the mean values of the individual morphological character among different six populations of $B$. vagra. The characters expressing significant differences were subjected to the discriminant function analysis (DFA) and principal component analysis (PCA). The principal component analysis helps in morphometeric data reduction (Veasey et al. 2001), in decreasing redundance among the variables (Samaee et al. 2006) and in extracting a number of independent variables for population differentiation (Samaee et al. 2009). The standardized coefficients are used to compare variables measured on different scales. Coefficients with large absolute values correspond to variables with greater discriminating ability.

The DFA was used to calculate the percentage of correctly classified (PCC) fish. The Wilks' lambda test of DFA was used to compare the differences between six populations, each three of which were collected from two geographically distinct river basins of Indian Himalaya. Statistical analysis for morphometric data were performed using the SPSS (ver. 16.1) and Microsoft Excel 2007.
List of extracted 90 truss generated morphometric measurements of Barilius vagra.

\begin{tabular}{|c|c|c|}
\hline & $\begin{array}{l}\text { Landmark } \\
\text { No. }\end{array}$ & Particulars of Truss distance \\
\hline 1 & $1-2$ & Tip of snout to the anterior border of eye \\
\hline 2 & $1-3$ & Tip of the snout to the posterior border of eye \\
\hline 3 & $1-4$ & Tip of snout to the posterior border of operculum \\
\hline 4 & $1-5$ & Tip of snout to end of frontal bone \\
\hline 5 & $1-6$ & Tip of snout to pectoral fin origin \\
\hline 6 & $1-7$ & Tip of snout to dorsal fin origin \\
\hline 7 & $1-8$ & Tip of snout to pelvic fin origin \\
\hline 8 & $1-9$ & Tip of snout to dorsal fin termination \\
\hline 9 & $1-10$ & Tip of snout to origin of anal fin \\
\hline 10 & $1-11$ & Tip of snout to termination of anal fin \\
\hline 11 & $1-12$ & Tip of snout to dorsal side of caudal peduncle \\
\hline 12 & $1-13$ & Tip of snout to ventral side of caudal peduncle \\
\hline 13 & $1-14$ & Tip of snout to termination of lateral line \\
\hline 14 & $2-3$ & Anterior border of eye to posterior border of eye \\
\hline 15 & $2-4$ & $\begin{array}{l}\text { Anterior border of eye to posterior border of } \\
\text { operculum }\end{array}$ \\
\hline 16 & $2-5$ & Anterior border of eye to end of frontal bone \\
\hline 17 & $2-6$ & Anterior border of eye to pectoral fin origin \\
\hline 18 & $2-7$ & Anterior border of eye to dorsal fin origin \\
\hline 19 & $2-8$ & Anterior border of eye to pelvic fin origin \\
\hline 20 & $2-9$ & Anterior border of eye to dorsal fin termination. \\
\hline 21 & $2-10$ & Anterior border of eye to origin of anal fin \\
\hline 22 & $2-11$ & Anterior border of eye to termination of anal fin \\
\hline 23 & $2-12$ & Anterior border of eye to dorsal side of caudal peduncle \\
\hline 24 & $2-13$ & $\begin{array}{l}\text { Anterior border of eye to ventral side of caudal } \\
\text { peduncle }\end{array}$ \\
\hline 25 & $2-14$ & Anterior border of eye to termination of lateral line \\
\hline 26 & $3-4$ & $\begin{array}{l}\text { Posterior border of eye to posterior border of } \\
\text { operculum }\end{array}$ \\
\hline 27 & $3-5$ & Posterior border of eye to end of frontal bone \\
\hline 28 & $3-6$ & Posterior border of eye to pectoral fin origin \\
\hline 29 & $3-7$ & Posterior border of eye to dorsal fin origin \\
\hline 30 & $3-8$ & Posterior border of eye to pelvic fin origin \\
\hline 31 & $3-9$ & Posterior border of eye to dorsal fin termination \\
\hline 32 & $3-10$ & Posterior border of eye to origin of anal fin \\
\hline 33 & $3-11$ & Posterior border of eye to termination of anal fin \\
\hline 34 & $3-12$ & $\begin{array}{l}\text { Posterior border of eye to dorsal side of caudal } \\
\text { peduncle }\end{array}$ \\
\hline 35 & $3-13$ & $\begin{array}{l}\text { Posterior border of eye to ventral side of caudal } \\
\text { peduncle }\end{array}$ \\
\hline 36 & $3-14$ & Posterior border of eye to termination of lateral line \\
\hline 37 & $4-5$ & Posterior border of operculum to end of frontal bone \\
\hline 38 & $4-6$ & Posterior border of operculum to pectoral fin origin \\
\hline 39 & $4-7$ & Posterior border of operculum to dorsal fin origin \\
\hline 40 & $4-8$ & Posterior border of operculum to pelvic fin origin \\
\hline 41 & $4-9$ & Posterior border of operculum to dorsal fin termination \\
\hline 42 & $4-10$ & Posterior border of operculum to origin of anal fin \\
\hline 43 & $4-11$ & $\begin{array}{l}\text { Posterior border of operculum to termination of anal } \\
\text { fin }\end{array}$ \\
\hline 44 & $4-12$ & $\begin{array}{l}\text { Posterior border of operculum to dorsal side of caudal } \\
\text { peduncle. }\end{array}$ \\
\hline
\end{tabular}




\begin{tabular}{|c|c|c|}
\hline & $\begin{array}{c}\text { Landmark } \\
\text { No. }\end{array}$ & Particulars of Truss distance \\
\hline 45 & $4-13$ & $\begin{array}{l}\text { Posterior border of operculum to ventral side of caudal } \\
\text { peduncle }\end{array}$ \\
\hline 46 & $4-14$ & $\begin{array}{l}\text { Posterior border of operculum to termination of lateral } \\
\text { line }\end{array}$ \\
\hline 47 & $5-6$ & End of frontal bone to pectoral fin origin \\
\hline 48 & $5-7$ & End of frontal bone to dorsal fin origin \\
\hline 49 & $5-8$ & End of frontal bone to pelvic fin origin \\
\hline 50 & $5-9$ & End of frontal bone to dorsal fin termination \\
\hline 51 & $5-10$ & End of frontal bone to origin of anal fin \\
\hline 52 & $5-11$ & End of frontal bone to termination of anal fin \\
\hline 53 & $5-12$ & End of frontal bone to dorsal side of caudal peduncle \\
\hline 54 & $5-13$ & End of frontal bone to ventral side of caudal peduncle \\
\hline 55 & $5-14$ & End of frontal bone to termination of lateral line \\
\hline 56 & $6-7$ & Pectoral fin origin to dorsal fin origin \\
\hline 57 & $6-8$ & Pectoral fin origin to pelvic fin origin \\
\hline 58 & $6-9$ & Pectoral fin origin to dorsal fin termination \\
\hline 59 & $6-10$ & Pectoral fin origin to origin of anal fin \\
\hline 60 & $6-11$ & Pectoral fin origin to termination of anal fin \\
\hline 61 & $6-12$ & Pectoral fin origin to dorsal side of caudal peduncle \\
\hline 62 & $6-13$ & Pectoral fin origin to ventral side of caudal peduncle \\
\hline 63 & $6-14$ & Pectoral fin origin to termination of lateral line \\
\hline 64 & $7-8$ & Dorsal fin origin to pelvic fin origin \\
\hline 65 & $7-9$ & Dorsal fin origin to dorsal fin termination \\
\hline 66 & $7-10$ & Dorsal fin origin to origin of anal fin \\
\hline 67 & $7-11$ & Dorsal fin origin to termination of anal fin \\
\hline 68 & $7-12$ & Dorsal fin origin to dorsal side of caudal peduncle \\
\hline 69 & $7-13$ & Dorsal fin origin to ventral side of caudal peduncle \\
\hline 70 & $7-14$ & Dorsal fin origin to termination of lateral line \\
\hline 71 & $8-9$ & Pelvic fin origin to dorsal fin termination \\
\hline 72 & $8-10$ & Pelvic fin origin to origin of anal fin \\
\hline 73 & $8-11$ & Pelvic fin origin to termination of anal fin \\
\hline 74 & $8-12$ & Pelvic fin origin to dorsal side of caudal peduncle \\
\hline 75 & $8-13$ & Pelvic fin origin to ventral side of caudal peduncle \\
\hline 76 & $8-14$ & Pelvic fin origin to origin of anal fin \\
\hline 77 & $9-10$ & Dorsal fin termination to origin of anal fin \\
\hline 78 & $9-11$ & Dorsal fin termination to termination of anal fin \\
\hline 79 & $9-12$ & Dorsal fin termination to dorsal side of caudal peduncle \\
\hline 80 & $9-13$ & $\begin{array}{l}\text { Dorsal fin termination to ventral side of caudal } \\
\text { peduncle }\end{array}$ \\
\hline 81 & $9-14$ & Dorsal fin termination to termination of lateral line \\
\hline 82 & $10-11$ & Origin of anal fin to termination of anal fin \\
\hline 83 & $10-12$ & Origin of anal fin to dorsal side of caudal peduncle \\
\hline 84 & $10-13$ & Origin of anal fin to ventral side of caudal peduncle \\
\hline 85 & $10-14$ & Origin of anal fin to termination of lateral line \\
\hline 86 & $11-12$ & $\begin{array}{l}\text { Termination of anal fin to dorsal side of caudal } \\
\text { peduncle }\end{array}$ \\
\hline 87 & $11-13$ & $\begin{array}{l}\text { Termination of anal fin to ventral side of caudal } \\
\text { peduncle }\end{array}$ \\
\hline 88 & $11-14$ & Termination of anal fin to termination of lateral line \\
\hline 89 & $12-13$ & $\begin{array}{l}\text { Dorsal side of caudal peduncle to ventral side of caudal } \\
\text { peduncle }\end{array}$ \\
\hline 90 & $13-14$ & $\begin{array}{l}\text { Ventral side of caudal peduncle to termination of lateral } \\
\text { line }\end{array}$ \\
\hline
\end{tabular}

Table 1. GPS coordinates of sites from Alaknanda and Chenab River basins.

\begin{tabular}{|l|c|c|c|c|}
\hline $\begin{array}{l}\text { Sampling } \\
\text { site }\end{array}$ & Sample size & $\begin{array}{c}\text { Latitude } \\
\left({ }^{\circ} \mathrm{N}\right)\end{array}$ & $\begin{array}{c}\text { Longitude } \\
\left({ }^{\circ} \mathrm{E}\right)\end{array}$ & $\begin{array}{c}\text { Altitude } \\
(\mathrm{m})\end{array}$ \\
\hline Dugadda & 42 & 30.26 & 78.72 & 740 \\
\hline Khankhara & 46 & 30.23 & 78.93 & 668 \\
\hline Khandah & 44 & 30.19 & 78.78 & 718 \\
\hline Dudhar & 40 & 32.92 & 75.03 & 486 \\
\hline Jhajar & 46 & 32.87 & 74.99 & 555 \\
\hline Jhuni & 39 & 32.89 & 75.95 & 754 \\
\hline
\end{tabular}

\section{RESULTS}

The morphometric characters between two sexes of $B$. vagra did not differ significantly $(p>0.05)$, hence the data for both sexes were pooled for all subsequent analysis. Univariate analysis of variance (ANOVA) extracted eighty morphometyric measurements having significant differences $(p<0.05)$ and 10 measurements $(1-7,2-4,3-4,3-7,4-5,5-7,7-12,7-13,8-9$, and 9-11) did not show significant differences among six populations of $B$. vagra. Principal component analysis (PCA) of these significant measurements extracted 13 principal components having eigenvalues greater than one (Figure 2) explaining cumulative variance of 94.79\%. The first principal component (PC1) accounted for $21.55 \%$ of the variation followed by $18.62 \%, 13.86 \%$, $8.01 \%$, and $6.52 \%$ variance, respectively by second, third, fourth, and fifth principal component (Table 2). Forward stepwise discriminant analysis of the significant variables produced five discriminant functions (DFs). The first, second, third, fourth and fifth discriminant functions explained $68.4 \%, 18.4 \%, 6.8 \%, 5.1 \%$, and $1.3 \%$ of variance, respectively (Table 3 ). Plotting DF1 and DF2 showed clear specimen differentiation of stocks from different tributaries, Dudhar, Jhajjar, and Jhuni streams of Chenab River basin. However; slight intermingling in the population of Barilius vagra from three different tributaries, Dugadda, Khandah, and Khankhra of Alaknanda river basin was also noticed (Figure 3).

Thirteen truss morphometric measurements 1-6, 1-13, 2-5, 2-6, 2-14, 3-6, 4-6, 4-14, 6-12, 7-8, 7-9, 10-11, and 13-14 contributed largely in the discriminant function analysis of B. vagra (Table 4). A total of $81.7 \%$ of specimens of Barilius vagra were classified into their original groups. Maximum $87.0 \%$ and minimum $76.2 \%$ of the specimens were found in their own groups of Khankhra and Dugadda streams, respectively from the Alaknanda river basin (Table 5). Some mixing in the 


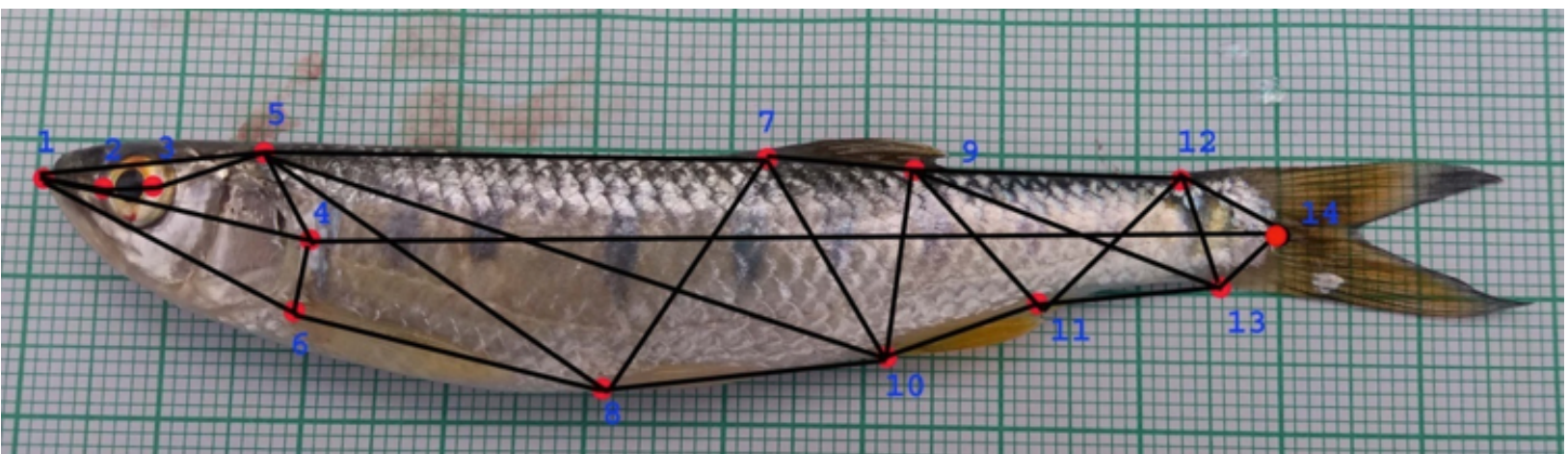

Image 1. Barilius vagra showing 14 morphometric landmarks and truss network: 1-Tip of snout | 2-end of eye towards mouth | 3-end of eye towards tail | 4-end of operculum | 5-forehead (end of frontal bone) | 6-dorsal origin of pectoral fin | 7-origin of dorsal fin | 8-origin of pelvic fin | 9-termination of dorsal fin | 10-origin of anal fin | 11-termination of anal fin | 12-dorsal side of caudal peduncle | 13ventral side of caudal peduncle | 14-end of lateral line.

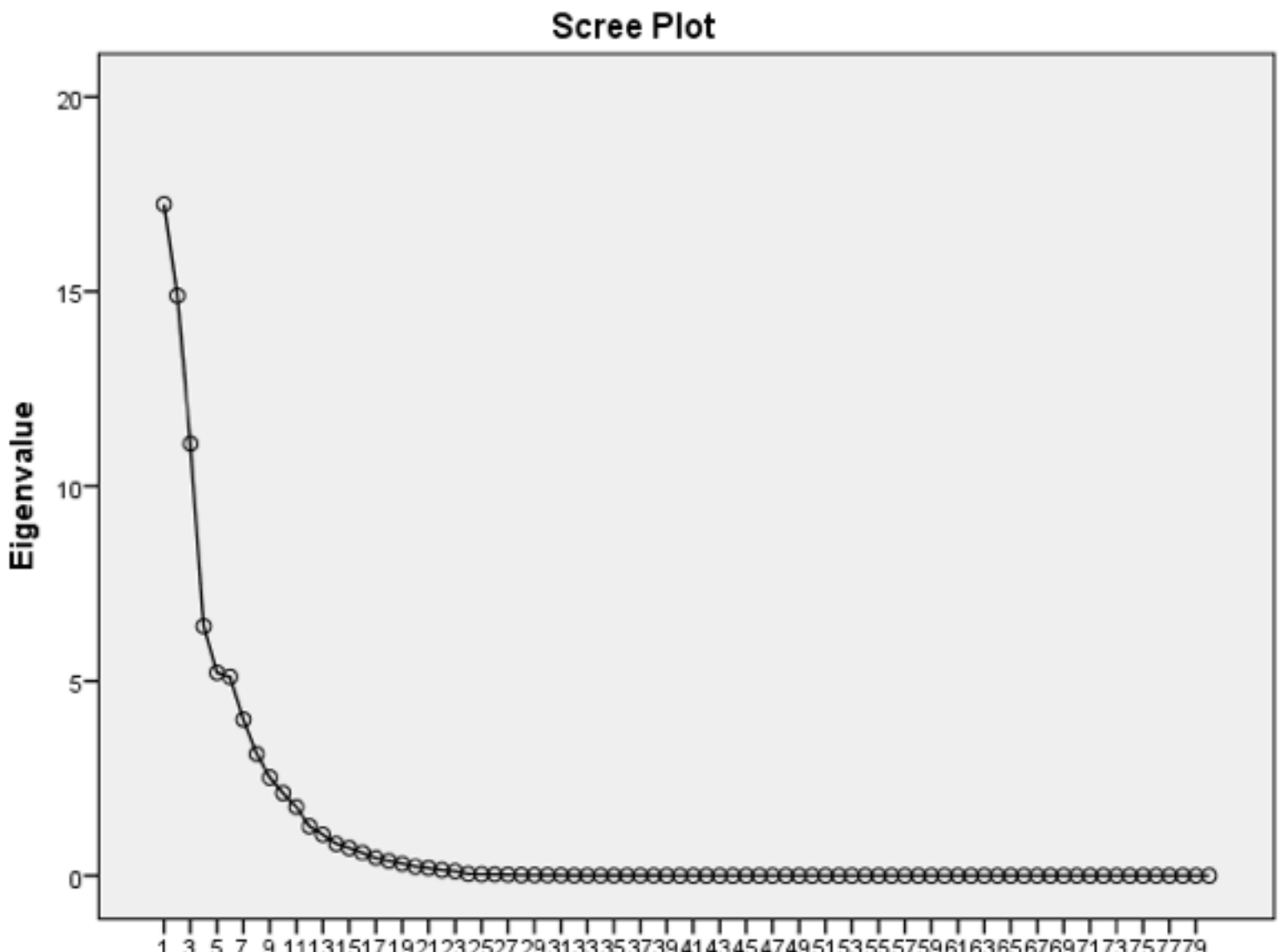

\section{Component Number}

Figure 1. Principal component analysis plot showing maximum variance explained by 13 significant truss morphometric measurements of Barilius vagra collected from tributaries of Alaknanda and Chenab rivers.

populations of Alaknanda river basin was also found. Wilks' Lambda test reflected highly significant variations among the six populations of $B$. vagra from different tributaries of Alaknanda and Chenab River basins (Table 6).

\section{DISCUSSION}

Morphological differentiation can enable individuals to survive with existing environmental variability (Senay et al. 2015). Hossain et al. (2010) reported that 
Table 2. Eigenvalues, percentage of variance and percentage of cumulative variance for the 13 PCs in case of morphometric measurements for Barilius vagra.

\begin{tabular}{|c|c|c|c|}
\hline \multirow{2}{*}{ Component } & \multicolumn{3}{|c|}{ Eigenvalues } \\
\cline { 2 - 4 } & Total & \% of Variance & Cumulative \% \\
\hline PC 1 & 17.244 & 21.555 & 21.555 \\
\hline PC 2 & 14.895 & 18.618 & 40.173 \\
\hline PC 3 & 11.090 & 13.862 & 54.035 \\
\hline PC 4 & 6.407 & 8.009 & 62.045 \\
\hline PC 5 & 5.213 & 6.516 & 68.561 \\
\hline PC 6 & 5.106 & 6.383 & 74.944 \\
\hline PC 7 & 4.011 & 5.014 & 79.958 \\
\hline PC 8 & 3.127 & 3.909 & 83.867 \\
\hline PC 9 & 2.523 & 3.154 & 87.021 \\
\hline PC 10 & 2.125 & 2.656 & 89.677 \\
\hline PC11 & 1.765 & 2.206 & 91.884 \\
\hline PC 12 & 1.268 & 1.585 & 93.469 \\
\hline PC 13 & 1.056 & 1.320 & 94.789 \\
\hline
\end{tabular}

Table 3. Eigenvalues and total variance explained by five discriminant functions.

\begin{tabular}{|c|c|c|c|c|}
\hline \multicolumn{5}{|c|}{ Eigenvalues } \\
\hline Function & Eigenvalue & $\%$ of Variance & Cumulative \% & $\begin{array}{c}\text { Canonical } \\
\text { Correlation }\end{array}$ \\
\hline DF 1 & $5.878^{\mathrm{a}}$ & 68.4 & 68.4 & 0.924 \\
\hline DF 2 & $1.582^{\mathrm{a}}$ & 18.4 & 86.8 & 0.783 \\
\hline DF 3 & $0.584^{\mathrm{a}}$ & 6.8 & 93.6 & 0.607 \\
\hline DF 4 & $0.438^{\mathrm{a}}$ & 5.1 & 98.7 & 0.552 \\
\hline DF 5 & $0.109^{\mathrm{a}}$ & 1.3 & 100.0 & 0.313 \\
\hline${ }^{\mathrm{a}}$ First 5 canonical discriminant functions were used in the analysis. \\
\hline \multicolumn{5}{|c}{} \\
\hline
\end{tabular}

phenotypic plasticity is very high in fishes. A sufficient degree of isolation may result in phenotypic and genetic differentiation among fish populations within a species (Turan et al. 2004). Franssen et al. (2013) also suggested that the selective pressure of the environmental conditions leading to genetic-environmental interactions influence the pattern of phenotypic variation at intraspecific level. The results of the present study showed significant phenotypic heterogeneity among the populations of $B$. vagra from two geographically distinct river basins. High level of morphometric differentiation was reported within the Chenab River basin as compared to the Alaknanda river basin as shown by the DFA plot. Chenab River is largely fragmented as compared to the Alaknanda river basin, might be one of the reasons for the cause.
Table 4. Discriminant function coefficients expressed by different morphometric measurements of Barilius vagra collected from tributaries of Alaknanda and Chenab rivers. (Bold digits indicates largest absolute correlation between each variable and any discriminant function)

\begin{tabular}{|l|c|c|c|c|c|}
\hline \multicolumn{5}{|c|}{ Standardized canonical discriminant function coefficients } \\
\hline \multirow{2}{*}{ Variables } & \multicolumn{5}{|c|}{ Function } \\
\cline { 2 - 6 } & DF 1 & DF 2 & DF 3 & DF 4 & DF 5 \\
\hline VAR 1-6 & 0.550 & 1.044 & -0.003 & 0.556 & -0.896 \\
\hline VAR 1-13 & -0.310 & -0.046 & $\mathbf{0 . 6 5 2}$ & -0.447 & 0.112 \\
\hline VAR 2-5 & 0.033 & -0.026 & 0.197 & $\mathbf{0 . 7 0 2}$ & 0.418 \\
\hline VAR 2-6 & 1.895 & -0.705 & 0.779 & -1.366 & $\mathbf{2 . 3 1 9}$ \\
\hline VAR 2-14 & 0.040 & 1.232 & -0.664 & -1.299 & -0.139 \\
\hline VAR 3-6 & -1.515 & -0.409 & -0.730 & 1.021 & -1.842 \\
\hline VAR 4-6 & 0.183 & 0.594 & -0.098 & 0.578 & $\mathbf{0 . 6 0 6}$ \\
\hline VAR 4-14 & 1.195 & -0.482 & 1.176 & 1.388 & 0.386 \\
\hline VAR 6-12 & -0.798 & -0.342 & -0.640 & -0.080 & 0.299 \\
\hline VAR 7-8 & 0.237 & -0.063 & -0.438 & -0.151 & -0.457 \\
\hline VAR 7-9 & -0.201 & $\mathbf{0 . 4 5 3}$ & 0.316 & 0.177 & -0.152 \\
\hline VAR 10-11 & -0.148 & 0.035 & $\mathbf{0 . 3 7 4}$ & -0.337 & -0.084 \\
\hline VAR 13-14 & -0.649 & 0.141 & 0.304 & -0.526 & 0.048 \\
\hline
\end{tabular}

Discriminant function analysis (DFA) could be a useful method to distinguish different stocks of the same species (Karakousis et al. 1991). In the present study, $81.7 \%$ of specimens were classified into their original groups by DFA, showing high variation in the stocks of Alaknanda and Chenab River basins. Eighty truss measurements in the whole body from head to tail were found to have significant differences $(p<0.05)$ among the six populations of both the river basins. 13 morphometric measurements $(1-6,1-13,2-5,2-6$, 2-14, 3-6, 4-6, 4-14, 6-12, 7-8, 7-9, 10-11, and 13-14) extracted from DFA largely contributed in the discrimination of six populations. These all variations in the morphometric measurements of fishes were attributed to the environmental conditions of those particular streams and the fishes adapted to the existing environmental conditions by altering their morphology. It was interesting to note that most of these parameters were linked to the head, eye diameter and fin (Dorsal and anal) of the fish body. Rajput et al. (2013) while studying the eco-morphology of Schizothorax richardsonii reported strong correlation between the environmental variables and morphometric parameters like the fin morphology and body shape. Sajina et al. (2011) studied the stock structure of Megalepis cordyla from the east (Bay of Bengal) and west coast (Arabian Sea) of the Indian 
Table 5. Number and percentage of correctly classified specimens of Barilius vagra into their original populations from Alaknanda (1, 2, 3) and Chenab $(4,5,6)$ river basins.

\begin{tabular}{|c|c|c|c|c|c|c|c|c|}
\hline \multicolumn{9}{|c|}{ Pridicted Group Membership } \\
\hline \multirow{2}{*}{\multicolumn{2}{|c|}{ Variables }} & \multicolumn{3}{|c|}{ Alaknanda River } & \multicolumn{3}{|c|}{ Chenab River } & \multirow{2}{*}{ Total } \\
\hline & & Dugadda & Khankhra & Khandah & Dudhar & Jhajjar & Jhuni & \\
\hline \multirow{12}{*}{ 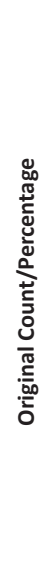 } & 1.Dugadda & 32 & 5 & 5 & 0 & 0 & 0 & 42 \\
\hline & 2.Khankhra & 2 & 40 & 4 & 0 & 0 & 0 & 46 \\
\hline & 3.Khandah & 8 & 1 & 34 & 0 & 1 & 0 & 44 \\
\hline & 4.Dudhar & 0 & 0 & 0 & 32 & 8 & 0 & 40 \\
\hline & 5.Jhajjar & 0 & 0 & 1 & 2 & 39 & 4 & 46 \\
\hline & 6.Jhuni & 0 & 0 & 0 & 1 & 5 & 33 & 39 \\
\hline & 1.Dugadda & 76.2 & 11.9 & 11.9 & 0.0 & 0.0 & 0.0 & 100.0 \\
\hline & 2.Khankhra & 4.3 & 87.0 & 8.7 & 0.0 & 0.0 & 0.0 & 100.0 \\
\hline & 3.Khandah & 18.2 & 2.3 & 77.3 & 0.0 & 2.3 & 0.0 & 100.0 \\
\hline & 4.Dudhar & 0.0 & 0.0 & 0.0 & 80.0 & 20.0 & 0.0 & 100.0 \\
\hline & 5.Jhajjar & 0.0 & 0.0 & 2.2 & 4.3 & 84.8 & 8.7 & 100.0 \\
\hline & 6.Jhuni & 0.0 & 0.0 & 0.0 & 2.6 & 12.8 & 84.6 & 100.0 \\
\hline
\end{tabular}

Table 6. Results of Wilks' lambda (function 1 through 5) for verifying differences among the stocks of Barilius vagra.

\begin{tabular}{|c|c|c|c|c|}
\hline \multicolumn{5}{|c|}{ Wilks' Lambda } \\
\hline $\begin{array}{c}\text { Test of } \\
\text { Function(s) }\end{array}$ & $\begin{array}{c}\text { Wilks' } \\
\text { Lambda }\end{array}$ & Chi-square & df & Significance \\
\hline 1 through 5 & 0.022 & 937.579 & 65 & 0.000 \\
\hline 2 through 5 & 0.153 & 462.231 & 48 & 0.000 \\
\hline 3 through 5 & 0.396 & 228.375 & 33 & 0.000 \\
\hline 4 through 5 & 0.627 & 114.932 & 20 & 0.000 \\
\hline 5 & 0.902 & 25.411 & 9 & 0.003 \\
\hline
\end{tabular}

peninsula using truss morphometric analysis and found significant heterogeneity among the stocks, attributed it to the uncommon hydrological conditions of habitats. Mir et al. (2013) investigated phenotypic variation in Schizothorax richardsonii from four rivers Jhelum, Lidder, Alaknanda, and Mandakini by using DFA and PCA and reported morphological discrimination among the stocks due to environmental factors.

Intermingling was noticed in three populations of Ganga River basin, which may be due to some common environmental conditions, migration and similar genetic origin at earlier period. Dwivedi et al. (2019) observed low level of morphometric differentiation among wild populations of Cirrhinus mrigala from ten different tributaries of Ganges and attributed it to the migration of individuals within the basin and common ancestry in the prehistoric period. In the present investigation Wilks $\lambda$ test of discriminant function analysis indicated significant differences in morphometric characters of six populations of $B$. vagra from two river basins, similar findings were reported by (Mir et al. 2013) in case of Schizothorax richardsonii.

Truss system can be successfully used to investigate stock separation within a species, as reported for other species in freshwater and marine environments. Among the 13 measurements which contributed to the five discriminant functions, four measurements $(2-6,3-6,4-6$, and $7-8)$ dominantly contributed to fifth discriminant function explaining variance in six populations of B. vagra. Mahfuj et al. (2019) while studying the meristic and morphometrics variations of Macrognathus pancalus using truss network system from the freshwaters of Bangladesh explained that out of fifteen truss measurements, five measurements contributed to the $1^{\text {st }} \mathrm{DF}$, six measurements contributed to the $2^{\text {nd }} D F$ and remaining four measurements to the $3^{\text {rd }}$ DF. Kenthao and Jearranaiprepame (2018) also conducted similar kind of study in Yclocheilichthys apogon from three different rivers Pong, Chi, and Mun of northeastern Thailand. The first three principal components explained 49.29\% of variance and first three discriminant functions explained $72 \%$ of variation among the samples. However, in the present study, PCA explained $94.79 \%$ of variance by using 13 principal components.

In this study, truss system revealed clear separation of $B$. vagra populations from two distinct river basins which will help in site-specific conservation and management strategies such as implementation of appropriate mesh 


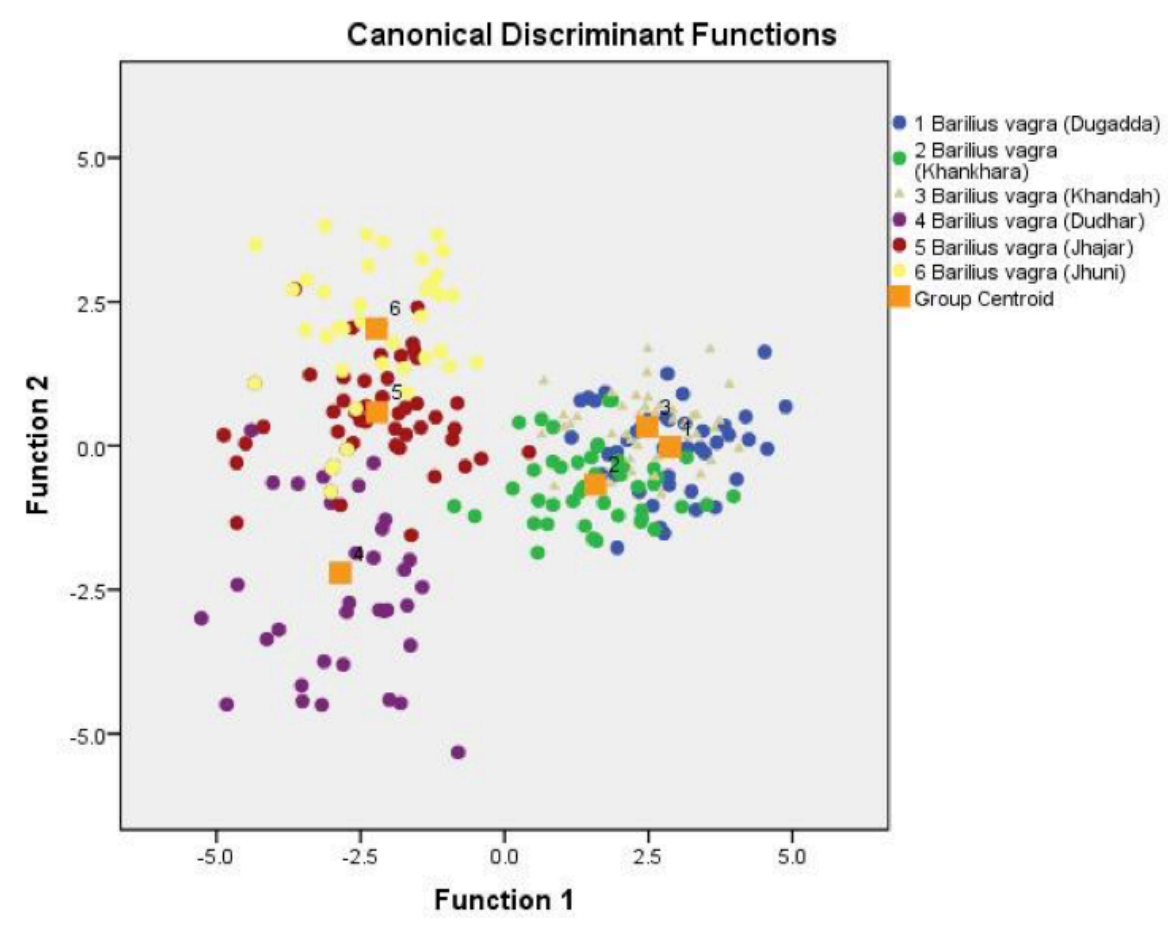

Figure 2. Discriminant analysis plot of Barilius vagra showing isolation of populations of Alaknanda and Chenab river basins.

sizes for fish harvesting, avoiding over-exploitation, augmentation of fish stock by culture, and making available sufficient food to fishes for their proper growth in different drainages of the Alaknanda and Chenab rivers. This will be instrumental in sustaining this resource for future use.

\section{CONCLUSION}

Truss protocol revealed phenotypic plasticity among six different populations of Alakanda and Chenab River drainages of Indian Himalaya. A clear separation of $B$. vagra populations between two geographically distinct river basins of Indian Himalaya was also found suggesting a need for separate conservation and management strategies to sustain the stock for future use.

\section{REFERENCES}

Begg, G.A., K.D. Friedland \& J.B. Pearce (1999). Stock identification and its role in stock assessment and fisheries management. Fisheries Research 43(1-3): 1-8. https://doi.org/10.1016/S01657836(99)00062-4

Cadrin, S.X. (2005). Morphometric landmarks. pp. 153-172. In: Cadrin S.X., K.D. Friedland \& J.R. Waldman (eds.). Stock Identification Methods. Elsevier Academic Press, UK, 736pp. https://doi. org/10.1016/B978-012154351-8/50008-3

Cavalcanti, M.J., L.R. Monteiro \& P.R.D. Lopez (1999). Landmark based morphometric analysis in selected species of serranid fishes (Perciformes: Teleostei). Zoological Studies 38: 287-294.

Das, S.P., D. Bej, S. Swain, C.K. Mishra, L. Sahoo, J. Jena \& P. Das (2014). Population divergence and structure of Cirrhinus mrigala from peninsular rivers of India, revealed by mitochondrial cytochrome $b$ gene and truss morphometric analysis. Mitochondrial DNA 25(2): 157-164. https://doi.org/10.3109/19401736.2013.792055

Dwivedi, A.K., U.K. Sarkar, J.I. Mir, P. Tomat \& V. Vyas (2019). The Ganges basin fish Cirrhinus mrigala (Cypriniformes: Cyprinidae): Detection of wild populations stock structure with landmark morphometry. Revista de Biologia Tropical 67(3): 541-553. http:/doi. org/10.15517/rbt.v67i3.34424

Elliott, N.G., K. Haskard \& J.A. Koslow (1995). Morphometric analysis of orange roughy (Hoplostethus atlanticus) off the continental slope of southern Australia. Journal of Fish Biology 46(2): 202-220. https:// doi.org/10.1111/j.1095-8649.1995.tb05962.x

Franssen, N.R., L.K. Stewart \& J.F. Schaefer (2013). Morphological divergence and flow-induced phenotypic plasticity in a native fish from anthropogenically altered stream habitats. Ecology and Evolution 3(14): 4648-4657. https://doi.org/10.1002/ece3.842

Garcia-Rodriguez F.J., S.A. Garcia-Gasca, J.D.L. Cruz-Aguero \& V.M. Cota-Gomez (2010). A study of the population structure of the Pacific sardine Sardinops sagax (Jenyns, 1842) in Mexico based on morphometric and genetic analyses. Fisheries Research 107: 169176. https://doi.org/10.1016/j.fishres.2010.11.002

Hammer, $\varnothing$., D.A.T. Harper \& P.D. Ryan (2001). PAST: Paleontological Statistics Software Package for Education and Data Analysis. Palaeontologia Electronika 4(1): 9. http://palaeo-electronica. org/2001_1/past/issue1_01.htm.

Hossain, M.A., M.D. Nahiduzzaman, D. Saha, M.U.H. Khanam \& M.S. Alam (2010). Landmark-based morphometric and meristic variations of the endangered carp, kalibaus Labeo calbasu, from stocks of two isolated rivers, the Jamuna and Halda, and a hatchery. Zoological Studies 49(4): 556-563.

Ihssen, P.E., H.E. Booke, J.M. Casselman, J.M. McGlade, N.R. Payne \& E.M. Utter (1981). Stock identification: Materials and methods. Canadian Journal of Fisheries and Aquatic Sciences 38: 1838-1855. 
https://doi.org/10.1139/f81-230

Karakousis, Y., C. Triantaphyllidis \& P.S. Economidis (1991) Morphological variability among seven populations of brown trout, Salmon trutta L., in Greece. Journal of Fish Biology 38(6): 807-817. https://doi.org/10.1111/j.1095-8649.1991.tb03620.x

Kenthao, A. \& P. Jearranaiprepame (2018). Morphometric variations and fishery unit assessment of Cyclocheilichthys apogon (Actinopterigii: Cyprinidae) from three-different rivers in NorthEastern Thailand. Pakistan Journal of Zoology 50(1): 111-122. https://doi.org/10.17582/journal.pjz/2018,50,1.11.122

Khan, M.A., K. Miyan \& S. Khan (2012). Morphometric variation of snakehead fish, Channa punctatus, populations from three Indian rivers. Journal of Applied Ichthyology 29(3): 637-642. https://doi. org/10.1111/j.1439-0426.2012.02058.x

Kullander, S.O., F. Fang, B. Delling \& E. Ahlander (1999). The fishes of Kashmir valley, pp. 99-167. In: Nyman L. (ed.). River Jhelum, Kashmir Valley. Swedmar, The International Consultancy Group of the National Board of Fisheries, Goteborgs, Lanstryckeri AB, Swedmar.

Kumar, S. \& D. Singh (2019). Genetic and morphometric comparison of two isolated populations of Barilius bendelisis (Cypriniformes: Cyprinidae) from the Indian Himalayas. Revista de Biología Tropical 67(3): 466-477. https://doi.org/10.15517/rbt.v67i3.33522

Mahfuj, M.S.E., A. Khatun, P. Boidya \& M.A. Samad (2019). Meristic and morphometric variations of Barred spiny eel Macrognathus pancalus populations from Bangladeshi Freshwaters: An Insight into Landmark-Based Truss Network System. Croatian Journal of Fisheries 77(1): 7-18. https://doi.org/10.2478/cjf-2019-0002

Mir, F.A., J.I. Mir \& S. Chandra (2013). Phenotypic variation in the Snowtrout Schizothorax richardsonii (Gray, 1832) (Actinopterygii: Cypriniformes: Cyprinidae) from the Indian Himalayas. Contributions to Zoology 82(3): 115-122. https://doi.org/10.1163/1875986608203001

Mir, F.A., J.I. Mir \& S. Chandra (2014). Detection of morphometric differentiation in Sattar snowtrout, Schizothorax curvifrons (Cypriniformes: Cyprinidae) from Kashmir Himalaya using a truss network system. Revista de Biologia Tropical 62(1): 132-141.

Mir, J.I., N. Saxena, R.S. Patiyal \& P.K. Sahoo (2015). Phenotypic differentiation of Barilius bendelisis (Cypriniformes: Cyprinidae) in four rivers from Central Indian Himalaya. Revista de Biologia Tropical 63(1): 165-173. https://doi.org/10.15517/rbt.v63i1.14252

Mirza, M.R. (1991). A contribution to the systematic of the Schizothoracine fishes (Pisces: Cyprinidae) with the description of three new tribes. Pakistan Journal of Zoology 23: 339-341.

Miyan, K., M.A. Khan, D.K. Patel, S. Khan \& N.G. Ansari (2015). Truss morphometry and otolith microchemistry reveal stock discrimination in Clarias batrachus (Linnaeus, 1758) inhabiting the Gangetic River system. Fisheries Research 173: 294-302.

Pinheiro, A., C.M. Teixeira, A.L. Rego, J.F. Marques \& H.N. Cabral (2005). Genetic and morphological variation of Solea lascaris (Risso, 1810) along the Portuguese coast. Fisheries Research 73: 67-78. https://doi.org/10.1016/j.fishres.2005.01.004

Poulet, N., P. Berrebi, A.J. Crivelli, S. Lek \& C. Argillier (2004). Genetic and morphometric variations in the pikeperch (Sander lucioperca L.) of a fragmented delta. Archiv fur Hydrobiologie 159: 531-554. https://doi.org/10.1127/0003-9136/2004/0159-0531

Rahman, A.K.A. (1989). Freshwater Fishes of Bangladesh. $1^{\text {st }}$ Edition, Zoological Society of Bangladesh, Department of Zoology, University of Dhaka, Dhaka-1000, pp. 113-114

Rajput V, J.A. Johnson \& K. Sivakumar (2013). Environmental effects on the morphology of the snow trout Schizothorax richardsonii (Gray, 1832). Taprobanica 5(2): 102-110. https://doi.org/10.4038/tapro. v5i2.6283

Rohlf, F.J. (2006). tpsDig2, ver. 2.1. State University of New York, Stony Brook.

Sahoo, P.K., S.K. Saikia \& D.N. Das (2009). Natural food resources and niche breadth of Barilius bendelisis (Hamilton) (Pisces, Cyprinidae) in river Dikrong, an upland riverine ecosystem in India. Pan-American Journal of Aquatic Sciences 4(1): 12-16.
Sahoo, S., A.R. Subbalakshmi \& M.K. Jolly (2020). The fundamentals of phenotypic plasticity, pp. 1-21. In: Levine, H., M. Kumar, J.P. Kulkarni \& V. Nanjundiah (eds.). Phenotypic Switching: Implications in Biology and Medicine. Academic Press, 762 pp.

Sajina, A.M., S.K. Chakraborty, A.K. Jaiswar, D.G. Pazhayamadam \& D. Sudheesan (2011). Stock structure analysis of (Megalaspis cordyla) (Linnaeus, 1758) along the Indian coast based on truss network analysis. Fisheries Research 108(1): 100-105. https://doi. org/10.1016/j.fishres.2010.12.006

Samaee, S.M., B. Mojazi-Amiri \& S.M. Hosseini-Mazinani (2006). Comparison of Capoeta capoeta gracilis (Cyprinidae, Teleostei) populations in the south Caspian Sea River basin, using morphometric ratios and genetic markers. Folia Zoologica 55: 323-335.

Samaee, M., R.A. Patzner \& N. Mansour (2009). Morphological differentiation within the population of Siah Mahi, Capoeta capoeta gracilis (Cyprinidae, Teleostei) in a river of the south Caspian Sea basin: a pilot study. Journal of Applied Ichthyology 25: 583590. https://doi.org/10.1111/j.1439-0426. 2009.01256.x

Sarkar, U.K., J.I. Mir, A.K. Dwivedi, A. Pal \& J. Jena (2014). Pattern of phenotypic variation among three populations of Indian major carp, Catla catla (Hamilton, 1822) using truss network system in the Ganga basin, India. Proceedings of the National Academy of Sciences, India Section B: Biological Sciences 84(4): 1005-1012. https://doi. org/10.1007/s40011-014-0303-1

Saxena, N., K. Dube, R.S. Patiyal \& V.K. Tiwari (2015). Meristic and morphometric differentiation in wild populations of Barilius bendelisis (Hamilton 1807) from Kumaun region of Uttarakhand, India. Fishery Technology 52(4): 205-212. https://www.researchgate. net/publication/288180601

Sen, S., S. Jahageerdar, A.K. Jaiswar, S.K. Chakraborty, A.M. Sajina \& G.R. Dash, (2011). Stock structure analysis of (Decapterus russelli) (Ruppell, 1830) from east and west coast of India using truss network analysis. Fisheries Research 112(1-2): 38-43. https://doi. org/10.1016/j.fishres.2011.08.008

Senay, C., D. Boisclair \& P.R. Peres-Neto (2015). Habitat-based polymorphism is common in stream fishes. Journal of Animal Ecology 84(1): 219-227. https://doi.org/10.1111/1365-2656.12269

Singh, A.K., R. Kumar, A.K. Mishra, M. Singh, V.S. Baisvar, U.K. Chauhan \& N.S. Nagpure (2016). Authentication of five Barilius species from Indian waters using DNA barcoding. Russian Journal of Genetics 52(8): 840-846. https://doi.org/10.1134/S1022795416060119

Strauss, R.E. \& F.L. Bookstein (1982). The truss: body form reconstructions in morphometrics. Systematic Biology 31(2): 113135. https://doi.org/10.1093/sysbio/31.2.113

Takács, P., Z. Vitál, Á. Ferincz \& Á. Staszny (2016). Repeatability, reproducibility, separative power and subjectivity of different fish morphometric analysis methods. PloS One 11(6): e0157890. https:// doi.org/10.1371/journal.pone.0157890

Talwar, P.K. \& A.G. Jhingran (1991). Inland Fishes of India and Adjacent Countries. Vol 2. Oxford and IBH Publishing Co. Pvt. Ltd., 1158 pp.

Turan, C. (1999). A note on the examination of morphometric differentiation among fish populations: the truss system. Turkish Journal of Zoology 23: 259-263.

Turan, C., D. Erguden, M. Gurlek, N.Basusta \& F. Turan (2004). Morphometric structuring of the anchovy (Engraulis encrasicolus L.) in the black, Aegean and northeastern Mediterranean seas. Turkish Journal of Veterinary and Animal Sciences 28: 865-871. https:// www.researchgate.net/publication/259755095

Veasey, E.A., E.A. Schammass, R. Vencovsky, P.S. Martins \& G. Bandel (2001). Germplasm characterization of Sesbania accessions based on multivariate analyses. Genetic Resources and Crop Evolution 48: 79-90. https://doi.org/10.1023/A:1011238320630

Wimberger, P.H. (1992). Plasticity of fish body shapes, the effects of diet, development, family and age in two species of Geophagus (Pisces: Cichlidae). Biological Journal of Linnean Society 45: 197-218. https://doi.org/10.1111/j.1095-8312.1992.tb00640.x 

Dr. John Noyes, Natural History Museum, London, UK

Dr. Albert G. Orr, Griffith University, Nathan, Australia

Dr. Sameer Padhye, Katholieke Universiteit Leuven, Belgium

Dr. Nancy van der Poorten, Toronto, Canada

Dr. Kareen Schnabel, NIWA, Wellington, New Zealand

Dr. R.M. Sharma, (Retd.) Scientist, Zoological Survey of India, Pune, India

Dr. Manju Siliwal, WILD, Coimbatore, Tamil Nadu, India

Dr. G.P. Sinha, Botanical Survey of India, Allahabad, India

Dr. K.A. Subramanian, Zoological Survey of India, New Alipore, Kolkata, India

Dr. P.M. Sureshan, Zoological Survey of India, Kozhikode, Kerala, India

Dr. R. Varatharajan, Manipur University, Imphal, Manipur, India

Dr. Eduard Vives, Museu de Ciències Naturals de Barcelona, Terrassa, Spain

Dr. James Young, Hong Kong Lepidopterists' Society, Hong Kong

Dr. R. Sundararaj, Institute of Wood Science \& Technology, Bengaluru, India

Dr. M. Nithyanandan, Environmental Department, La Ala Al Kuwait Real Estate. Co. K.S.C.,

Kuwait

Dr. Himender Bharti, Punjabi University, Punjab, India

Mr. Purnendu Roy, London, UK

Dr. Saito Motoki, The Butterfly Society of Japan, Tokyo, Japan

Dr. Sanjay Sondhi, TITLI TRUST, Kalpavriksh, Dehradun, India

Dr. Nguyen Thi Phuong Lien, Vietnam Academy of Science and Technology, Hanoi, Vietnam

Dr. Nitin Kulkarni, Tropical Research Institute, Jabalpur, India

Dr. Robin Wen Jiang Ngiam, National Parks Board, Singapore

Dr. Lional Monod, Natural History Museum of Geneva, Genève, Switzerland.

Dr. Asheesh Shivam, Nehru Gram Bharti University, Allahabad, India

Dr. Rosana Moreira da Rocha, Universidade Federal do Paraná, Curitiba, Brasi

Dr. Kurt R. Arnold, North Dakota State University, Saxony, Germany

Dr. James M. Carpenter, American Museum of Natural History, New York, USA

Dr. David M. Claborn, Missouri State University, Springfield, USA

Dr. Kareen Schnabel, Marine Biologist, Wellington, New Zealand

Dr. Amazonas Chagas Júnior, Universidade Federal de Mato Grosso, Cuiabá, Brasil

Mr. Monsoon Jyoti Gogoi, Assam University, Silchar, Assam, India

Dr. Heo Chong Chin, Universiti Teknologi MARA (UiTM), Selangor, Malaysia

Dr. R.J. Shiel, University of Adelaide, SA 5005, Australia

Dr. Siddharth Kulkarni, The George Washington University, Washington, USA

Dr. Priyadarsanan Dharma Rajan, ATREE, Bengaluru, India

Dr. Phil Alderslade, CSIRO Marine And Atmospheric Research, Hobart, Australia

Dr. John E.N. Veron, Coral Reef Research, Townsville, Australia

Dr. Daniel Whitmore, State Museum of Natural History Stuttgart, Rosenstein, Germany.

Dr. Yu-Feng Hsu, National Taiwan Normal University, Taipei City, Taiwan

Dr. Keith V. Wolfe, Antioch, California, USA

Dr. Siddharth Kulkarni, The Hormiga Lab, The George Washington University, Washington,

D.C., USA

Dr. Tomas Ditrich, Faculty of Education, University of South Bohemia in Ceske

Budejovice, Czech Republic

Dr. Mihaly Foldvari, Natural History Museum, University of Oslo, Norway

Dr. V.P. Uniyal, Wildlife Institute of India, Dehradun, Uttarakhand 248001, India

Dr. John T.D. Caleb, Zoological Survey of India, Kolkata, West Bengal, India

Dr. Priyadarsanan Dharma Rajan, Ashoka Trust for Research in Ecology and the Environment

(ATREE), Royal Enclave, Bangalore, Karnataka, India

\section{Fishes}

Dr. Neelesh Dahanukar, IISER, Pune, Maharashtra, India

Dr. Topiltzin Contreras MacBeath, Universidad Autónoma del estado de Morelos, México

Dr. Heok Hee Ng, National University of Singapore, Science Drive, Singapore

Dr. Rajeev Raghavan, St. Albert's College, Kochi, Kerala, India

Dr. Robert D. Sluka, Chiltern Gateway Project, A Rocha UK, Southall, Middlesex, UK

Dr. E. Vivekanandan, Central Marine Fisheries Research Institute, Chennai, India

Dr. Davor Zanella, University of Zagreb, Zagreb, Croatia

Dr. A. Biju Kumar, University of Kerala, Thiruvananthapuram, Kerala, India

Dr. Akhilesh K.V., ICAR-Central Marine Fisheries Research Institute, Mumbai Research

Centre, Mumbai, Maharashtra, India

Dr. J.A. Johnson, Wildlife Institute of India, Dehradun, Uttarakhand, India

Amphibians

Dr. Sushil K. Dutta, Indian Institute of Science, Bengaluru, Karnataka, India

Dr. Annemarie Ohler, Muséum national d'Histoire naturelle, Paris, France

\section{Reptiles}

Dr. Gernot Vogel, Heidelberg, Germany

Dr. Raju Vyas, Vadodara, Gujarat, India

Dr. Pritpal S. Soorae, Environment Agency, Abu Dubai, UAE.

Prof. Dr. Wayne J. Fuller, Near East University, Mersin, Turkey

Prof. Chandrashekher U. Rivonker, Goa University, Taleigao Plateau, Goa. India

Dr. S.R. Ganesh, Chennai Snake Park, Chennai, Tamil Nadu, India

Dr. Himansu Sekhar Das, Terrestrial \& Marine Biodiversity, Abu Dhabi, UAE
Birds

Dr. Hem Sagar Baral, Charles Sturt University, NSW Australia

Dr. Chris Bowden, Royal Society for the Protection of Birds, Sandy, UK

Dr. Priya Davidar, Pondicherry University, Kalapet, Puducherry, India

Dr. J.W. Duckworth, IUCN SSC, Bath, UK

Dr. Rajah Jayapal, SACON, Coimbatore, Tamil Nadu, India

Dr. Rajiv S. Kalsi, M.L.N. College, Yamuna Nagar, Haryana, India

Dr. V. Santharam, Rishi Valley Education Centre, Chittoor Dt., Andhra Pradesh, India

Dr. S. Balachandran, Bombay Natural History Society, Mumbai, India

Mr. J. Praveen, Bengaluru, India

Dr. C. Srinivasulu, Osmania University, Hyderabad, India

Dr. K.S. Gopi Sundar, International Crane Foundation, Baraboo, USA

Dr. Gombobaatar Sundev, Professor of Ornithology, Ulaanbaatar, Mongolia

Prof. Reuven Yosef, International Birding \& Research Centre, Eilat, Israel

Dr. Taej Mundkur, Wetlands International, Wageningen, The Netherlands

Dr. Carol Inskipp, Bishop Auckland Co., Durham, UK

Dr. Tim Inskipp, Bishop Auckland Co, Durham, UK

Dr. V. Gokula, National College, Tiruchirappalli, Tamil Nadu, India

Dr. Arkady Lelej, Russian Academy of Sciences, Vladivostok, Russia

Dr. Simon Dowell, Science Director, Chester Zoo, UK

Dr. Mário Gabriel Santiago dos Santos, Universidade de Trás-os-Montes e Alto Douro,

Quinta de Prados, Vila Real, Portugal

Dr. Grant Connette, Smithsonian Institution, Royal, VA, USA

Dr. M. Zafar-ul Islam, Prince Saud Al Faisal Wildlife Research Center, Taif, Saudi Arabia

Mammals

Dr. Giovanni Amori, CNR - Institute of Ecosystem Studies, Rome, Italy

Dr. Anwaruddin Chowdhury, Guwahati, India

Dr. David Mallon, Zoological Society of London, UK

Dr. Shomita Mukherjee, SACON, Coimbatore, Tamil Nadu, India

Dr. Angie Appel, Wild Cat Network, Germany

Dr. P.O. Nameer, Kerala Agricultural University, Thrissur, Kerala, India

Dr. Ian Redmond, UNEP Convention on Migratory Species, Lansdown, UK

Dr. Heidi S. Riddle, Riddle's Elephant and Wildlife Sanctuary, Arkansas, USA

Dr. Karin Schwartz, George Mason University, Fairfax, Virginia.

Dr. Lala A.K. Singh, Bhubaneswar, Orissa, India

Dr. Mewa Singh, Mysore University, Mysore, India

Dr. Paul Racey, University of Exeter, Devon, UK

Dr. Honnavalli N. Kumara, SACON, Anaikatty P.O., Coimbatore, Tamil Nadu, India

Dr. Nishith Dharaiya, HNG University, Patan, Gujarat, India

Dr. Spartaco Gippoliti, Socio Onorario Società Italiana per la Storia della Fauna "Giuseppe

Altobello", Rome, Italy

Dr. Justus Joshua, Green Future Foundation, Tiruchirapalli, Tamil Nadu, India

Dr. H. Raghuram, The American College, Madurai, Tamil Nadu, India

Dr. Paul Bates, Harison Institute, Kent, UK

Dr. Jim Sanderson, Small Wild Cat Conservation Foundation, Hartford, USA

Dr. Dan Challender, University of Kent, Canterbury, UK

Dr. David Mallon, Manchester Metropolitan University, Derbyshire, UK

Dr. Brian L. Cypher, California State University-Stanislaus, Bakersfield, CA

Dr. S.S. Talmale, Zoological Survey of India, Pune, Maharashtra, India

Prof. Karan Bahadur Shah, Budhanilakantha Municipality, Kathmandu, Nepal

Dr. Susan Cheyne, Borneo Nature Foundation International, Palangkaraja, Indonesia

Dr. Hemanta Kafley, Wildlife Sciences, Tarleton State University, Texas, USA

\section{Other Disciplines}

Dr. Aniruddha Belsare, Columbia MO 65203, USA (Veterinary)

Dr. Mandar S. Paingankar, University of Pune, Pune, Maharashtra, India (Molecular)

Dr. Jack Tordoff, Critical Ecosystem Partnership Fund, Arlington, USA (Communities)

Dr. Ulrike Streicher, University of Oregon, Eugene, USA (Veterinary)

Dr. Hari Balasubramanian, EcoAdvisors, Nova Scotia, Canada (Communities)

Dr. Rayanna Hellem Santos Bezerra, Universidade Federal de Sergipe, São Cristóvão, Brazil

Dr. Jamie R. Wood, Landcare Research, Canterbury, New Zealand

Dr. Wendy Collinson-Jonker, Endangered Wildlife Trust, Gauteng, South Africa

Dr. Rajeshkumar G. Jani, Anand Agricultural University, Anand, Gujarat, India

Dr. O.N. Tiwari, Senior Scientist, ICAR-Indian Agricultural Research Institute (IARI), New

Delhi, India

Dr. L.D. Singla, Guru Angad Dev Veterinary and Animal Sciences University, Ludhiana, India

Dr. Rupika S. Rajakaruna, University of Peradeniya, Peradeniya, Sri Lanka

Dr. Bahar Baviskar, Wild-CER, Nagpur, Maharashtra 440013, India

Reviewers 2018-2020

Due to pausity of space, the list of reviewers for $2018-2020$ is available online.

The opinions expressed by the authors do not reflect the views of the Journal of Threatened Taxa, Wildlife Information Liaison Development Society, Zoo Outreach Organization, or any of the partners. The journal, the publisher, the host, and the partners are not responsible for the accuracy of the political boundaries shown in the maps by the authors.

Journal of Threatened Taxa is indexed/abstracted in Bibliography of Systematic Mycology, Biological Abstracts, BIOSIS Previews, CAB Abstracts, EBSCO, Google Scholar, Index Copernicus, Index Fungorum, JournalSeek, National Academy of Agricultural Sciences, NewJour, OCLC WorldCat, SCOPUS, Stanford University Libraries, Virtual Library of Biology, Zoological Records.

NAAS rating (India) 5.64
Print copies of the Journal are available at cost. Write to:

The Managing Editor, JoTT,

c/o Wildlife Information Liaison Development Society,

No. 12, Thiruvannamalai Nagar, Saravanampatti - Kalapatti Road,

Saravanampatti, Coimbatore, Tamil Nadu 641035, India

ravi@threatenedtaxa.org 


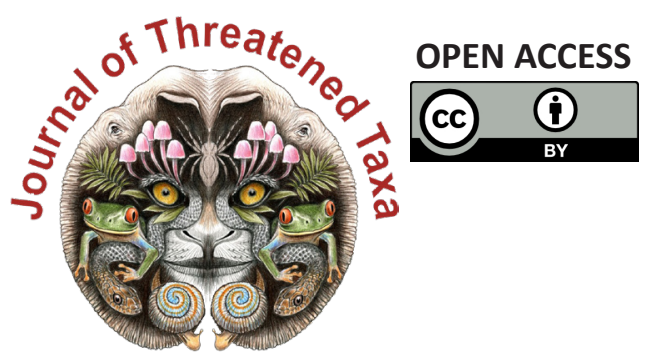

www.threatenedtaxa.org

The Journal of Threatened Taxa (JoTT) is dedicated to building evidence for conservation globally by publishing peer-reviewed articles online every month at a reasonably rapid rate at www.threatenedtaxa.org. All articles published in JoTT are registered under Creative Commons Attribution 4.0 International License unless otherwise mentioned. JoTT allows allows unrestricted use, reproduction, and distribution of articles in any medium by providing adequate credit to the author(s) and the source of publication.

ISSN 0974-7907 (Online) I ISSN $0974-7893$ (Print)

\section{November 2021 | Vol. 13 | No. 13 | Pages: 19887-20142 \\ Date of Publication: 26 November 2021 (Online \& Print) DOI: 10.11609/jott.2021.13.13.19887-20142}

\section{Article}

An inventory of geometrid moths (Lepidoptera: Geometroidea: Geometridae) of KalakadMundanthurai Tiger Reserve, India

- Geetha Iyer, Dieter Stüning \& Sanjay Sondhi, Pp. 19887-19920

\section{Communications}

Roadkills of Lowland Tapir Tapirus terrestris (Mammalia: Perissodactyla: Tapiridae) in one of its last refuges in the Atlantic Forest

- Aureo Banhos, Andressa Gatti, Marcelo Renan de Deus Santos, Leonardo Merçon,

Ilka Westermeyer, Natália Carneiro Ardente, Luis Francisco Oliveira Pereira Gonzaga, Lucas Mendes Barreto, Lucas Damásio, Tomas Lima Rocha, Vitor Roberto Schettino, Renata Valls, Helena Godoy Bergallo, Marcos Vinicius Freitas Silva, Athelson Stefanon Bittencourt, Danielle de Oliveira Moreira \& Ana Carolina Srbek-Araujo, Pp. 19921-19929

Scientific contributions and learning experiences of citizen volunteers with a small cat project in Sanjay Gandhi National Park, Mumbai, India

- Shomita Mukherjee, R. Nandini, P.V. Karunakaran \& Nayan Khanolkar, Pp. 19930-19936

Seasonal food preferences and group activity pattern of Blackbuck Antilope cervicapra (L., 1758) (Mammalia: Cetartiodactyla: Bovidae) in a semi-arid region of western Haryana, India

- Vikram Delu, Dharambir Singh, Sumit Dookia, Priya \& Kiran, Pp. 19937-19947

Studies on the habitats of Grey Francolin Francolinus pondicerianus (J.F. Gmelin, 1789) (Galliformes: Phasianidae) in northern districts of Tamil Nadu, India

- M. Pandian, Pp. 19948-19955

Recovery of vulture population in roosting and scavenging areas of Bastar and Bijapur, Chhattisgarh, India

- Sushil Kumar Dutta, Muntaz Khan, P.R.S. Nagi, Santosh Durgam \& Surabhi Dutta, Pp. 19956-19963

A geographical assessment of Chariganga and Arpara Beel (wetlands) of Nadia, West Bengal as a habitat of wetland birds

- Mehedi Hasan Mandal, Arindam Roy \& Giyasuddin Siddique, Pp. 19964-19975

Phenotypic plasticity in Barilius vagra (Hamilton, 1822) (Teleostei: Danionidae) from two geographically distinct river basins of Indian Himalaya

- Sumit Kumar, Sharali Sharma \& Deepak Singh, Pp. 19976-19984

Taxonomic notes, a new species, and a key to Indian species of the click beetle genus Cryptalaus Ôhira, 1967 (Coleoptera: Elateridae: Agrypninae)

- Harshad Parekar \& Amol Patwardhan, Pp. 19985-19999

Niche overlap of benthic macrofauna in a tropical estuary: diurnal variation

- Mário Herculano de Oliveira, Lidiane Gomes de Lima, Caroline Stefani da Silva Lima, Jéssica de Oliveira Lima Gomes, Franciely Ferreira Paiva, Graciele de Barros, Carlinda Railly Medeiros \& Joseline Molozzi, Pp. 20000-20010

Diversity of aquatic insects and biomonitoring of water quality in the upper Ganga River, a Ramsar site: a preliminary assessment

- Kritish De, Arkojyoti Sarkar, Kritika Singh, Virendra Prasad Uniyal, Jeyaraj Antony Johnson \& Syed Ainul Hussain, Pp. 20011-20018

Patterns of forest cover loss in the terrestrial Key Biodiversity Areas in the Philippines: critical habitat conservation priorities

- Bernard Peter O. Daipan, Pp. 20019-20032

The woody flora of Shettihalli Wildlife Sanctuary, central Western Ghats of Karnataka, India - A checklist

- Kanda Naveen Babu, Kurian Ayushi, Vincy K. Wilson, Narayanan Ayyappan \&

Narayanaswamy Parthasarathy, Pp. 20033-20055

Reproductive biology of Ophiorrhiza caudata C.E.C.Fisch. (Rubiaceae), an endemic and endangered creeping perennial herb of the Western Ghats, India

- Maria Theresa, Appukuttan Kamalabai Sreekala \& Jayalakshmi Mohanlal, Pp. 20056-20065
Short Communications

Successful rescue, medical management, rehabilitation, and translocation of a Red Panda Ailurus fulgens (Mammalia: Carnivora: Ailuridae) in Arunachal Pradesh, India - Jahan Ahmed, Sorang Tadap, Millo Tasser, Koj Rinya, Nekibuddin Ahmed \& Sunil Kyarong, Pp. 20066-20071

A rare photographic record of Eurasian Otter Lutra lutra with a note on its habitat from the Bhagirathi Basin, western Himalaya, India

- Ranjana Pal, Aashna Sharma, Vineet Kumar Dubey, Tapajit Bhattacharya, Jeyaraj Antony Johnson, Kuppusamy Sivakumar \& Sambandam Sathyakumar, Pp. 20072-20077

The first record of Medog Gliding Frog Rhacophorus translineatus Wu, 1977 (Anura: Rhacophoridae) from Chhukha District, Bhutan

- Sonam Lhendup \& Bal Krishna Koirala, Pp. 20078-20083

First record of a freshwater crab, Maydelliathelphusa masoniana (Henderson, 1893) (Decapoda: Brachyura: Gecarcinucidae) from West Bengal, India

- Ram Krishna Das, Pp. 20084-20089

Butterflies of Amrabad Tiger Reserve, Telangana, India

- Deepa Jaiswal, B. Bharath, M. Karuthapandi, Shrikant Jadhav, S. Prabakaran \& S. Rehanuma Sulthana, Pp. 20090-20097

An enumeration of the flowering plants of Kyongnosla Alpine Sanctuary in eastern Sikkim, India

- Sudhansu Sekhar Dash, Subhajit Lahiri \& Ashiho Asoshii Mao, Pp. 20098-20117

A new record of psychrotrophic Paecilomyces formosus (Eurotiales: Ascomycota) from India: morphological and molecular characterization

- Skarma Nonzom \& Geeta Sumbali, Pp. 20118-20123

Notes

Study on incidence and pathology of gastrointestinal parasitic infections in Nilgai Boselaphus tragocamelus in Hisar, Haryana, India

- Maneesh Sharma, B.L. Jangir, D. Lather, G.A. Chandratre, V. Nehra, K.K. Jakhar \& G. Narang, Pp. 20124-20127

An unusual vocalization of Brown Hawk-Owl Ninox scutulata (Raffles, 1822) (Aves:

Strigiformes: Strigidae) recorded from Kerala, India

- Riju P. Nair \& Shine Raj Tholkudiyil, Pp. 20128-20129

New distribution data on the genus Maripanthus Maddison, 2020 (Araneae: Salticidae) from southern India

- A. Asima, John T.D. Caleb, Dhruv A. Prajapati \& G. Prasad, Pp. 20130-20132

On the IUCN status of Boesenbergia albolutea and B. rubrolutea (Zingiberaceae) and typification of $B$. rubrolutea

- K. Aishwarya \& M. Sabu, Pp. 20133-20135

New records of mass seeding Cephalostachyum latifolium Munro (Poaceae) along the midelevation broadleaved forest of Sarpang district, Bhutan

- Jigme Tenzin, Sangay Nidup \& Dago Dorji, Pp. 20136-20139

Response

If habitat heterogeneity is effective for conservation of butterflies in urban landscapes of Delhi, India?' Unethical publication based on data manipulation

- Sanjay Keshari Das \& Rita Singh, Pp. 20140-20142

Publisher \& Host
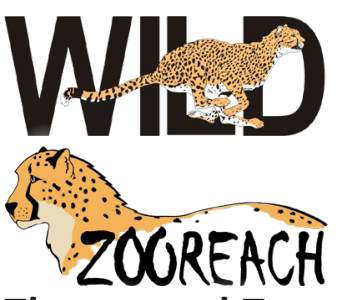

Threatened Taxa 